\title{
КУРС ЗА ВИБОРОМ «АКТУАЛЬНІ ПРОБЛЕМИ ЦЕРЕБРОВАСКУЛЯРНОЇ ПАТОЛОГІЇ» - ОСОБЛИВОСТІ ВПРОВАДЖЕННЯ В УМОВАХ ДИСТАНЦЙНОГО НАВЧАННЯ
}

\author{
S. I. Shkrobot, Z. V. Salii, M. I. Salii, Kh. V. Duve \\ I. Horbachevsky Ternopil National Medical University \\ THE ELECTIVE COURSE “CURRENT PROBLEMS OF \\ CEREBROVASCULAR PATHOLOGY” - THE PECULIARITIES \\ OF IMPLEMENTATION IN DISTANCE EDUCATION
}

\begin{abstract}
Анотація. У статті висвітлено особливості впровадження в освітній процес елективного курсу «Актуальні питання цереброваскулярної патології» в умовах дистанційного навчання. В 2020-2021 навчальному році вперше студентам випускного курсу Тернопільського національного медичного університету імені І. Я. Горбачевського МОЗ України було запропоновано поглибити свої знання з неврології. Метою курсу за вибором було вдосконалення знань студентів про основні симптоми і синдроми ураження нервової системи при судинній патології головного мозку. Ключовим завданням елективного курсу було поглибити теоретичні знання з актуальної проблеми сучасної медицини та закласти основи для формування клінічного мислення. Проте пандемія COVID-19 внесла суттєві корективи в освітній процес. Навчання проводилося дистанційно на основі платформи Microsoft Teams. 3 метою забезпечення актуальності курсу викладачі підготували теоретичний матеріал із використанням найсучасніших даних та підсумків клінічних досліджень, опублікованих у провідних наукових виданнях. Особливу увагу приділено сучасним вимогам Національної служби здоров’я України щодо тактики ведення пацієнтів з інсультом. До кожної із 10 тем викладачами кафедри підібрані відеофрагменти, які мали на меті значно розширити уявлення студентів про кожну нозологію. На кожному занятті для закріплення матеріалу ми використовували розбір клінічних ситуацій як із власного досвіду, так і запозичених з літературних джерел.

Буде враховано результати опитування студентів за підсумками дистанційного навчання при плануванні наступних курсів за вибором і вдосконалимо вже напрацьовані матеріали та методики.
\end{abstract}

Ключові слова: елективний курс; неврологія; судинна патологія головного мозку.

Abstract. This article reveals the peculiarities of the implementation of the elective course "Actual issues of cerebrovascular pathology" into the educational process in distance learning conditions. It was the first time, in the 2020-2021 academic year when the graduate students of I. Horbachevsky Ternopil National Medical University were proposed to improve their knowledge of the neurology subject. The main aim of this elective course was to deepen students' knowledge of the main nervous system symptoms and syndromes due to vascular pathology of the brain. The key task of the elective course was to improve the theoretical knowledge about the current problem of modern medicine and to pave the way for further clinical thinking. However, the COVID-19 pandemic has made significant adjustments to the educational process. The educational course was conducted remotely on the Microsoft Teams platform. Lecturers have prepared theoretical material using the latest data and results of clinical trials published in advanced scientific journals to ensure the relevance of this course. Particular attention is paid to the management of stroke patients due to the current requirements of The National Health Service of Ukraine. In order to expand and improve students' understanding of each nosology, teachers have selected video fragments for each of the 10 topics. During each class we applied clinical cases from our own experience as well as from the literature sources.

For future selective courses students' surveys will be taken into account in order to refine all the previous inputs.

Key words: elective course; neurology; cerebrovascular pathology of the brain.

(c) С. І. Шкробот, 3. В. Салій, М. І. Салій, Х. В. Дуве 
Вступ. «Курс за вибором», або «елективний курс», - цей термін з'явився у вітчизняній методичній літературі більше двох десятиліть тому. Основне спрямування такого виду навчання - компенсувати досить обмежені можливості базового курсу.

Завдання, які повинен вирішити елективний курс, такі: розширення змісту базового курсу; поглиблення і модифікація його змісту; сприяння професійному самовизначенню; забезпечення прогресивного розвитку індивідуальної освітньої траєкторії випускників [2]. У рамках академічної мобільності студент повинен мати можливість самостійно формувати частину навчальної програми, траєкторію навчального процесу, відповідно до своїх професійних інтересів [3].

Вибір теми курсу за вибором з предмета «Неврологія» обумовлений актуальністю проблеми цереброваскулярної патології, як для світової медицини в цілому, так і для України зокрема. Цереброваскулярна патологія є однією із найбільш актуальних медичних та соціальних проблем у всьому світі у зв’язку з високою смертністю (друге місце після серцево-судинних захворювань), інвалідизацією, втратою працездатності, розвитком деменції і високим ризиком розвитку повторного епізоду порушення мозкового кровообігу. За останні 10 років поширеність цереброваскулярних захворювань (ЦВ3) в Україні суттєво збільшилась [1].

Так, за даними Т. Meier і співавт. [4] у період спостереження 1990-2016 рр., Україна продемонструвала найвищу частку (38,2 \%) від загальної кількості смертей серед країн Європи. Що стосується стандартизованої за віком смертності від цереброваскулярної патології на 100000 жителів, то найвищі показники у Східній Європі були виявлені також в Україні (349 смертей на 100 000).

Не менш важливою є проблема хронічних порушень мозкового кровообігу - їх частка в структурі цереброваскулярної патології України може сягати 80-90\%. Оскільки провідним синдромом даної нозології $є$ когнітивне зниження різного ступеня тяжкості та низка інших порушень, які мають тенденцію до прогресування, то це обумовлює важливе медико-соціальне значення через лідируючі місця в структурі інвалідизуючих станів та витрати на догляд за такими пацієнтами.

Мультидисциплінарність даної проблеми (неврологи, кардіологи, ревматологи, судинні хірурги, психіатри, лікарі загальної практики - сімейної медицини, лікарі функціональної діагностики тощо) обгрунтовує її важливість та пріоритетність.
Мета статті - оцінити особливості викладання елективного курсу «Актуальні питання цереброваскулярної патології» студентам 6 курсу медичного факультету в умовах дистанційного навчання, зумовленого пандемією COVID-19.

Теоретична частина. Згідно з типовою навчальною програмою «Неврологія» для студентів 4 курсу зі спеціальності 222 «Медицина», на опанування складної проблеми «Судинної патології головного мозку» відводяться 4 лекційні години та 2 заняття за системою «Єдиного дня», що дозволяє на належному рівні опанувати лише базові поняття широкого спектра нозологій.

Тому студентам випускного (6) курсу ми запропонували поглибити свої знання шляхом залучення до індивідуальної освітньої траєкторії такого важливого розділу, як судинна патологія головного мозку.

Програма розрахована на 60 год (20 год - практичні заняття, 40 год - самостійна позааудиторна робота).

Метою циклу є вдосконалення знань студентів про основні симптоми і синдроми ураження нервової системи при судинній патології головного мозку, визначення етіологічних факторів та патогенетичних механізмів розвитку даної патології, проведення диференційної діагностики, планування тактики ведення неврологічного хворого.

Ми окреслили такі завдання:

- визначати основні симптоми і синдроми ураження різних відділів нервової системи при судинній патології головного мозку;

- визначити етіологічні фактори та патогенетичні механізми розвитку основних неврологічних захворювань при судинній патології головного мозку;

- аналізувати основні показники лабораторноінструментальних методів дослідження в неврологічній практиці;

- проводити диференційну діагностику;

- встановлювати клінічний діагноз;

- призначати лікування;

- проводити експертизу працездатності;

- призначати профілактичні заходи.

Здійснено підготовку робочої програми, методичних розробок і вказівок, а також методичних матеріалів з підготовки до практичного заняття. Усі методичні матеріали були розміщені у відповідному розділі в системі MOODLE на WEB-сторінці кафедри, що уже близько двох десятиліть є невід’ємною та обов’язковою складовою.

Плануючи вказаний курс, ми мали на меті поглибити та розширити обсяг не тільки теоретичних 
знань студентів. Важливим було під час огляду та розбору пацієнтів закласти основи для формування клінічного мислення, алгоритму діагностичного пошуку.

Ключові завдання сучасної медичної освіти спрямовані на те, щоб студенти були озброєні не лише теоретичними знаннями, але мали достатній практичний досвід. Компетенції клінічних навичок, включаючи навички спілкування, збір анамнезу, професійне ставлення, усвідомлення етичних основ здоров'я, фізичний огляд, процедурні та лабораторні навички, навички діагностики й терапевтичні, навички реанімації, навички командної роботи, організаційні, управлінські та навички з інформаційних технологій повинні бути невід'ємною частиною навчальних програм студентів [6].

При вивченні дисципліни планували використовувати адекватні методи навчання. Зокрема, за джерелами знань: словесні - розповідь, пояснення, міні-лекція, інструктаж; наочні - демонстрація, ілюстрація; практичні - практична робота, вирішення клінічних ситуаційних задач.

За характером логіки пізнання використовувалися методи: аналітичний, синтетичний, аналітико-синтетичний, індуктивний, дедуктивний. За рівнем самостійної розумової діяльності - проблемний, частково-пошуковий, дослідницький.

Кафедра неврології завжди робила акцент на якісному виконанні практичної частини заняття. Ми започаткували структуру заняття з обов'язковою подачею методики встановлення клінічного діагнозу та клінічного розбору пацієнтів за темою, заповненням протоколу обстеження пацієнта (свого роду міні-медичної карти). Самостійна робота студентів біля ліжка хворого передбачала реалізацію навичок на практиці з виділенням провідних клінічних синдромів, формулювання діагнозу, призначення плану обстеження та лікування.

Зацікавленість у вивченні курсу за вибором «Актуальні проблеми цереброваскулярної патології» висловили 55 студентів 6 курсу, що лише підтвердило правильність обраної нами теми та вмотивованість студентів.

Однак пандемія COVID-19 внесла свої корективи і навчання відбувалося дистанційно на основі платформи Microsoft Teams. Тобто робота біля ліжка хворого та виконання запланованої практичної частини були неможливими, що поставило перед викладачами нові виклики. Потрібно було переформатувати структуру заняття.
Заняття, тривалістю 2 академічні години, традиційно розпочиналося із бліц-опитування з метою розуміння якості та «глибини» самостійної підготовки студентів. До кожної із 10 тем викладачі кафедри підготували презентації теоретичного матеріалу, підібрали відеофрагменти, які мали на меті значно розширити уявлення студентів про кожну нозологію. Використовували найсучасніші дані, опубліковані в провідних наукових виданнях (Stroke, European J. Neurology, JAMA Neurology, Lancet, American J. Neuroradiology тощо), клінічні рекомендації ACA/ASA.

Окреме заняття ми присвятили початковим проявам недостатності кровопостачання головного мозку (згідно з Міжнародною класифікацією хвороб X перегляду (MKX-X), цій нозології можуть відповідати такі рубрики: G 43-G 47 (епізодичні та пароксизмальні розлади); G 90 (розлади автономної нервової системи, за відсутності наявних етіологічних чинників захворювання); G 99.2 (синдром хребтової артерії, який включає в себе клініку задньошийного симпатичного синдрому, епізоди дроп-атак, синдром Унтерхарншайдта); F 06.7 (легкі когнітивні розлади); F 06.6 (органічний емоційно-лабільний (астенічний) розлад) [5]. Це вказує на клінічне розмаїття дебюту цереброваскулярної недостатності, вимагає уваги й встановлення провідних чинників, виокремлення факторів ризику. Адже корекція семи (за даними American Heart Association) факторів ризику та адекватна терапія на стадії клінічних проявів сприятимуть зниженню числа інсультів та сповільнюватимуть прогресування хронічної мозкової недостатності.

Вивчаючи тему «Лакунарний інсульт», студенти мали змогу познайомитися із підсумками клінічних досліджень останніх 5 років (IST-3, WAKE-UP, PatieNts (SATURN)), що обгрунтовують діагностичну цінність різних методів нейровізуалізації (комп’ютерної томографії, перфузійної комп'ютерної томографії, магнітно-резонансної томографії), застосування тромболітичної терапії та статинів при цій нозології. Акцентувалася увага на понятті «німого інсульту» та високому ризику розвитку когнітивного зниження аж до деменції у пацієнтів із лакунарним інсультом. В межах цієї теми окреме повідомлення стосувалося «хвороби малих судин», що об'єднує різні патологічні стани і механізми, які призводять до ураження дрібних судин білої та сірої речовин головного мозку і спричиняють появу неврологічних, когнітивних та нейровізуальних феноменів. 
За межі аудиторної сітки базового предмета «Неврологія» виходили теми венозної патології головного мозку, PRES-синдрому, CADASIL й інших деменцій.

3 кожним десятиліттям проблема деменції набуває все більшої актуальності. Так, у Європі станом на 2015 р. таких пацієнтів було 10,5 млн, у 2030 р. (враховуючи негативні тенденції) очікується 13,4 млн, а у 2050 р. - 18,6 млн. Детально було подано характеристику, критерії діагностики хвороби Альцгеймера, церебральної амілоїдної ангіопатії, фронтотемпоральної деменції, судинної деменції, деменції з тільцями Леві, CADASIL. Акцентовано увагу на диференційних особливостях, параклінічних характеристиках окремих форм. Важливим було знайомство майбутніх лікарів із скринінговими шкалами, які слід застосовувати у рутинній клінічній практиці (MMSE, МоСА, Міні-ког, тест малювання годинника тощо). Критерії діагностики та клініка окремих стадій CADASIL були подані через призму конкретного клінічного випадку власного спостереження, ілюстрованого результатами нейровізуалізації та біопсії шкіри.

Восьме заняття було спрямоване на отримання знань студентами про таку нозологію, як гостра гіпертонічна енцефалопатія та PRES-синдром зокрема. 3 нею можуть стикнутися в практиці не лише неврологи, але і кардіологи, акушери-гінекологи, ревматологи, онкологи, хіміотерапевти, хірургитрансплантологи тощо. Це робить знання, отримані на занятті, особливо цінними. Акцентовано увагу на особливостях та диференційно-діагностичних МРТ-критеріях змін у головному мозку. Теоретичний матеріал ілюстровано численними клінічними ситуаціями типового та атипового варіантів PRES-синдрому.

Окреме заняття було присвячене протоколам надання допомоги пацієнтам із гострим ішемічним та геморагічним інсультом, які покроково прописують та регламентують алгоритм дії медичного працівника з надання екстреної, первинної, вторинної (спеціалізованої) допомоги. Оскільки останні були затверджені у 2012 та 2014 роках, ми акцентували увагу на сучасних вимогах Національної служби здоров’я України стосовно тактики ведення пацієнтів з інсультом, а також змінах, що стосувалися нових підходів до призначення тромболітичної терапії.
Серед усього розмаїття судинних захворювань проблема патології венозної системи головного мозку невиправдано перебуває у статусі «Попелюшки». На останньому практичному занятті ми розглянули особливості будови венозної системи головного мозку, провідні патогенетичні механізми, клінічні прояви синдрому хронічної венозної дисциркуляції та венозної енцефалопатії. Наголошено, що реальна частка такої патології не відповідає даним статистики, що вказує на недостатню інформованість лікарів щодо цих нозологій. Особливу увагу приділено тромбозам венозних синусів (кавернозного, поперечного, сигмоподібного, сагітального), гострому венозному інсульту. Проаналізовано переваги і недоліки методів діагностики (КТ-ангіографії та МРТ-ангіографії), а також основні напрямки лікування.

На кожному занятті для закріплення матеріалу ми використовували розбір клінічних ситуацій як із власного досвіду, так і запозичених із літературних джерел.

Студенти також мали можливість проявити креативність та хист у підготовці повідомлень 3 окремих питань, які доповідали на занятті. Цікавими були повідомлення про особливості кровопостачання головного мозку; авторегуляцію мозкового кровообігу; особливості клініки субарахноїдального крововиливу залежно від локалізації аневризми; хворобу Бінсвангера; напрямки, методи та ефективність ранньої реабілітації після інсульту; особливості клініки тромбозу венозних синусів.

Висновки та перспективи подальших досліджень. Однак, попри все вищезазначене, ми вважаємо що жоден яскравий презентаційний матеріал не зможе замінити той унікальний досвід, який здобувається під час живої дискусії в аудиторії, у спілкуванні з пацієнтом, вмінні самостійно виявити симптоми та інтерпретувати їх. Тому ми сподіваємося, що наступні курси за вибором будуть проходити в багатовіковому (з часів Гіппократа) форматі - Лікар - Учень - Пацієнт.

Ми врахуємо результати опитування студентів за підсумками дистанційного навчання при плануванні наступних курсів за вибором і вдосконалимо вже напрацьовані матеріали та методики. 


\section{Список літератури}

1. Коваленко О. Є. Хронічні цереброваскулярні розлади у осіб молодого віку: клініко-діагностичні, етіопатогенетичні та лікувально-профілактичні аспекти / О. Є. Коваленко, Б. Г. Гаврищук // Клінічна та профілактична медицина. - 2020. - Т. 4 (14). - С. 97-103.

2. Навчальна програма елективних курсів з іноземних мов для старшої школи ЗНЗ / [В. Г. Редько, Т. К. Полонська, Н. П. Басай та ін.] ; за наук. ред. В. Г. Редька. - К. : Педагогічна думка, 2015. - 41 с.

3. Сиволап В. Д. Особливості викладання елективного курсу «Актуальні питання кардіології» на кафедрі внутрішніх хвороб / В. Д. Сиволап, Д. А. Лашкул, С. М. Кисельов // Актуальні питання дистанційної освіти та телемедицини 2018 : матеріали Всеукр. наук.-метод.

\section{References}

1. Kovalenko, O.E., \& Havryshchuk, B.H. (2020). Khronichni tserebro-vaskuliarni rozlady u osib molodoho viku: kliniko-diahnostychni, etiopatohenetychni ta likuvalnoprofilaktychni aspekty [Chronic cerebrovascular disorders in young people: clinical-diagnostic, etiopathogenetic and treatment-and-prophylactic aspects]. Klinichna ta profilaktychna medytsyna - Clinical and Preventive Medicine, 4(14), 97-103 [in Ukrainian].

2. Redko, V.H., Polonska, T.K., Basai, N.P., Pasichnyk, O.S., Dolynskyi, Je.V., Basai, O.V., \& Alekseenko, I.V. (2015). Navchalna prohrama elektyvnykh kursiv z inozemnykh mov dlia starshoi shkoly ZNZ [Curriculum of elective courses in foreign languages for high school]. Kyiv: Pedahohichna dumka [in Ukrainian].

3. Syvolap, V.D., Lashkul, D.A., \& Kyselov, S.M. (2018). Osoblyvosti vykladannia elektyvnoho kursu “Aktualni pytannia kardiolohii” na kafedri vnutrishnikh khvorob [Features of teaching the elective course "Current issues of cardiology" at the Department of Internal Medicine]. Aktualni pytannia dystantsiinoi osvity ta telemedytsyny відеоконф. 3 міжнар. участю (Запоріжжя, 25-26 квіт. 2018 р.). - Запоріжжя ; К. : ЗДМУ, 2018. - С. 152-154.

4. Cardiovascular mortality attributable to dietary risk factors in 51 countries in the WHO European Region from 1990 to 2016: a systematic analysis of the Global Burden of Disease Study / T. Meier, K. Gräfe, F. Senn [et al.] // European journal of epidemiology. - 2019. - Vol. 34 (1). P. 37-55. https://doi.org/10.1007/s10654-018-0473-x.

5. International Statistical Classification of Diseases and Related Health Problems 10th Revision Version: 2019. URL : https:// icd.who.int/browse10/2019/en.

6. Technology-enhanced simulation for health professions education: a systematic review and meta-analysis / D. A. Cook, R. Hatala, R. Brydges, B. Zendejas [et al.] // JAMA. - 2011. - Vol. 306 (9). - P. 978-988.

2018: materialy Vseukr. nauk.-metod. videokonf. z mizhnar. uchastiu - Current issues of distance education and telemedicine 2018: materials All-Ukrainian scientific method videoconf. with international participation. Zaporizhzhia: ZDMU [in Ukrainian].

4. Meier, T., Gräfe, K., Senn, F., Sur, P., Stangl, G.I., Dawczynski, C., ... Lorkowski, S. (2019). Cardiovascular mortality attributable to dietary risk factors in 51 countries in the WHO European Region from 1990 to 2016: a systematic analysis of the Global Burden of Disease Study. European Journal of Epidemiology, 34(1), 37-55. https://doi. org/10.1007/s10654-018-0473-x.

5. International Statistical Classification of Diseases and Related Health Problems 10th Revision Version: 2019. URL: https:// icd.who.int/browse10/2019/en.

6. Cook, D.A., Hatala, R., Brydges, R., Zendejas, B., Szostek, J.H., Wang, A.T., ... Hamstra, S.J. Technologyenhanced simulation for health professions education: a systematic review and meta-analysis. JAMA, 306(9), 978988. 